\title{
The Impact of Smoking on the Therapy Outcomes in Patients With Pneumonia Infection at RSP (Pulmonary Hospital) Respira, Yogyakarta
}

\author{
Mega Octavia ${ }^{1, *}$ Pramitha Esha N.D ${ }^{2}$ Dianita Sugiyo ${ }^{3,4}$
}

\author{
${ }^{1}$ Department of Pharmacology and clinical pharmacy, Faculty of medicine and health science \\ Universitas Muhammadiyah Yogyakarta, Yogyakarta, Indonesia \\ ${ }^{2}$ Department of Pharmacy Profession, Faculty of medicine and health science, Universitas Muhammadiyah Yogyakarta, \\ Yogyakarta, Indonesia \\ ${ }^{3}$ School of nursing, Faculty of medicine and health science, Universitas Muhammadiyah Yogyakarta, Yogyakarta, Indonesia \\ ${ }^{4}$ Muhammadiyah Steps, Universitas Muhammadiyah Yogyakarta, Yogyakarta, Indonesia \\ *Corresponding author. Email: megaoctavia@umy.ac.id
}

\begin{abstract}
Smoking is known to cause interstitial lung diseases, such as interstitial pneumonia and the prognosis, which are well seen when patients quit smoking. Smoking cigarette negatively affects the effectiveness of therapy, cure rates, and a higher risk of recurrence in pulmonary TB. This study analyzes smoking habits' influence on therapy outcomes in patients with pneumonia infection at RSP (Pulmonary Hospital) Respira Yogyakarta. The researchers conducted an observational study with a cross-sectional study design and a retrospective data collection method employing medical records. Observations were carried out on pneumonia patients divided into two groups: the smoking and non-smoking groups. The data collection method used total sampling. The observed outcomes of therapy were the length of stay and the effectiveness of therapy. This study utilized chi-square as its statistical analysis. The 130 patients who met the criteria were divided into two groups: the smoking and non-smoking groups with 65 people each. The results revealed that the effectiveness of therapy in the smoking group had a $26 \%$ chance of recovery, an improvement of $61 \%$, and not-yet-cured of $13 \%$. Meanwhile, in the non-smoking group, they had a $47 \%$ chance of recovery, an improvement of $43 \%$ and not-yet-cured of $10 \%$. The statistical test results with Chi-square obtained $\mathrm{p}$-value of $<0.05(\mathrm{p}=$ 0.039). The results on the length of stay showed that $82 \%$ of patients in the smoking group and non-smoking group had a length of stay of $\leq 5$ days, and $12 \%$ of patients had a length of stay of $>5$ days in both group. Hence, smoking habits significantly affected therapy's effectiveness but did not significantly influence the length of stay.
\end{abstract}

Keywords: Smoking, pneumonia, outcome therapy

\section{INTRODUCTION}

Pneumonia is an infection of the lower respiratory tract caused by various pathogens, such as bacteria, viruses, fungi, and parasites[1]. According to the 2013 Association of Physician Indians, the number one cause of death in the United States was pneumonia. Every year, there was 5-10 million community-acquired pneumonia (CAP) cases, with 1.1 million CAP patients hospitalized and 45,000 CAP patients died[2].

Many factors cause an increase in mortality rate in pneumonia infection, both intrinsic and extrinsic factors. The intrinsic factor includes age, sex, nutritional status, immunization status, and low birth weight. Meanwhile, the extrinsic factors encompass occupancy density, house ventilation, air pollution, and cigarette smoke exposure. Of all these factors, the most common and significant causes of pneumonia are the extrinsic factors, including exposure to cigarette smoke, dust, and air pollution[1].
Moreover, Indonesia is the third-largest cigarette smoking country after India and China. In 2001-2012, the number of smokers in Indonesia increased from 182 billion to 260.8 billion. It was a very high number, considering the amount consumed was very large[2].

The type of cigarette often consumed is tobacco cigarettes, containing 4000 harmful compounds, such as nicotine, tar, and other compounds. Smoking adversely impacts the lung, including lung cancer, ovarian cancer, mouth and throat cancer, esophageal cancer, coronary heart disease, stroke, and chronic obstructive pulmonary disease. Besides, the increasing number of smokers can lead to various infectious diseases, such as invasive pneumococcal disease (IPD), community-acquired pneumonia (CAP), and meningococcal disease[3].

Further, smoking is one of the causes of interstitial lung disease, one of which is pneumonia[4]. The research explained that a smoker with infectious lung disease could worsen disease progression[5]. Other studies have disclosed that smoking can affect a therapy's effectiveness, the speed 
of healing, and the higher risk of pulmonary tuberculosis recurrence[6,7]. Also, smoking is a factor in reducing the length of stay in patients while being hospitalized[8].

Based on the retrospective cohort studies conducted in Armenia in 2014-2016, smoking habits could affect the effectiveness of therapy, the speed of healing, and a higher recurrence rate of pulmonary tuberculosis[7]. However, the risk of smoking is much greater towards the progress of a disease and impacts the costs incurred. As in a prospective study in 2015, cigarette consumption was estimated to cost more than $\$ 300$ billion a year, about $\$ 170$ billion in costs related to direct medical and lost productivity costs of around $\$ 156$ billion due to illness experienced by patients[9].

It is the high incidence and mortality rate associated with pneumonia and the effects of smoking. Thus, this study was conducted by looking at differences in therapy outcomes in patients with pneumonia and direct medical costs in patients with smoking habits.

\subsection{Research design and sample}

This study was conducted with a cross-sectional design in pneumonia patients at RSP Respira, Yogyakarta. The patient condition data were obtained from medical records, and the medical cost data were acquired from the hospital finances. All the data were then analyzed descriptively.

Sampling was conducted from January 2019 to December 2019, with a total sampling method that met the inclusion and exclusion criteria. Inclusion criteria included male patients who had information about smoking or not in the medical record, diagnosed with pneumonia, had comorbidities and received antibiotic therapy. Meanwhile, the exclusion criteria comprised incomplete medical records, patients who quit smoking, patients died while undergoing treatment, and patients referenced to other hospitals.

The population of this study was 207 medical records

that met the acceptance criteria. It consisted of 65 smoking patient medical records and 96 non-smoking patient medical records. Furthermore, the researchers equalized the proportion between the two groups by sampling 96 medical records of nonsmokers to 65 medical records.

\section{METHOD}

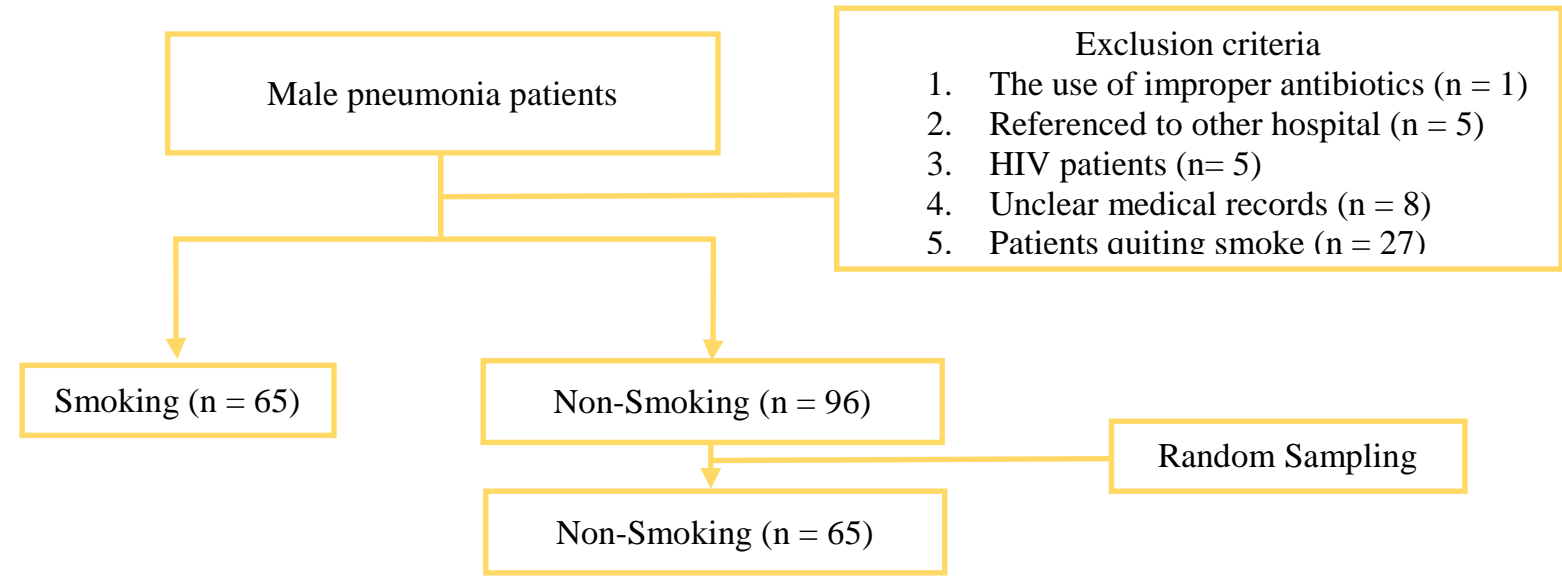

Figure 1. Research profile

\subsection{Procedure}

The researchers collected research materials and conducted literature studies to obtain the right research design. Prior to that, they carried out a preliminary test at the hospital and administered a research permit, waiting for the permit to be issued from the hospital so that they could retrieve research data with copies to the medical and financial records department. The researchers gathered all medical records of patients diagnosed with pneumonia that fulfilled the inclusion requirements. The collected medical record data that matched the acceptance criteria were then analyzed, applying the chi-square method on the therapy outcome to see the difference between smoking pneumonia patients and non-smoking pneumonia patients. The therapy outcome data inspected in this study were the effectiveness of therapy and length of stay, with characteristic data that included age, comorbidities, length of stay, and the number of antibiotics used.

\section{RESULTS}

During 2018 - 2019, a total population of 207 medical records was obtained. Those who fulfilled the inclusion criteria were 130 medical records, while 46 medical records 
were in the exclusion criteria. Exclusion to medical records included one medical record with unclear antibiotic use status, five medical records with referral status in other hospitals, five medical records with HIV diagnosis, eight medical records with unclear medical record status (no status of patients with smoking habits), and 27 medical records with smoke-quitting status. On the other hand, the number of medical records that met the inclusion criteria in the smoking group was 65 medical records and 96 medical records for the non-smoking group. In the group of nonsmoking patients, 65 medical records were randomly sampled to obtain the same proportion of samples.
Furthermore, patients who met the inclusion criteria would be observed further for several characteristics, including age, comorbidity status, and antibiotic use.

In the non-smoking group with a total of 65 patients, aged 56-65 were categorized as elderly in the highest position of patients diagnosed with pneumonia, with a total of 23 patients or $35.38 \%$ of the total non-smoking group. The late adolescent group aged 17-25 occupied the lowest position of patients diagnosed with pneumonia, namely one patient or $1.5 \%$ of the total smoking patients.

Table 1. Characteristics of Patients in the Smoking and Non-Smoking Groups

\begin{tabular}{cccc}
\hline Parameter & $\begin{array}{c}\text { Non-Smoking Group } \\
(\mathbf{n}=\mathbf{6 5})\end{array}$ & $\begin{array}{c}\text { Smoking Group } \\
(\mathbf{n}=\mathbf{6 5})\end{array}$ & p-Value \\
\hline \multicolumn{1}{c}{ Age } & $1(2 \%)$ \\
$26-35$ & $1(1 \%)$ & $2(3 \%)$ & 0,226 \\
$36-45$ & $2(3 \%)$ & $6(9 \%)$ & \\
$46-55$ & $3(5 \%)$ & $12(19 \%)$ & 0,652 \\
$56-65$ & $12(19 \%)$ & $23(35 \%)$ & \\
$>65$ & $12(19 \%)$ & $21(32 \%)$ & \\
\hline No Comorbid & $34(53 \%)$ & $28(43 \%)$ & \\
$1-2$ Comorbid & Comorbidity Status & $34(52 \%)$ & \\
$>2$ Comorbid & $23(35 \%)$ & $3(5 \%)$ & \\
\hline & $38(58 \%)$ & $28(43 \%)$ & \\
\hline No Comorbid & $4(7 \%)$ & $34(52 \%)$ & \\
\hline - Comorbid & Antibiotic Use & \\
\hline
\end{tabular}

In terms of comorbidity status, the researchers grouped the patients into three categories: no-comorbid, 1-2 comorbid, and $>2$ comorbid. The results revealed that 23 or $35 \%$ of patients were labeled as no-comorbid in the smoking group. Besides, 38 or $58 \%$ of patients were in 1-2 comorbid, and 4 or $7 \%$ of patients were detected comorbid $>2$. As for the non-smoking group, 28 patients or $43 \%$ were in comorbid non-smoking status. In the number of 1-2 comorbid, there were 34 or $52 \%$ of patients, and 3 or $5 \%$ of patients were in $>2$ comorbid.

Table 2. Types of comorbid in smoking and non-smoking group

\begin{tabular}{lccc}
\multicolumn{1}{c}{ Types of Comorbid } & $\begin{array}{c}\text { Smoking Group } \\
(\mathbf{n = 6 5 )}\end{array}$ & $\begin{array}{c}\text { Non-Smoking Group } \\
(\mathbf{n = 6 5 )}\end{array}$ & Total \\
\hline PPOK Eks* & $7(10 \%)$ & $0(0 \%)$ & $7(6 \%)$ \\
PPOK* & $6(9 \%)$ & $4(6 \%)$ & $10(8 \%)$ \\
Sepsis & $1(2 \%)$ & $1(2 \%)$ & $2(2 \%)$ \\
Stress Ulcer & $1(2 \%)$ & $0(0 \%)$ & $1(1 \%)$ \\
Hypovolemia & $1(2 \%)$ & $0(0 \%)$ & $1(1 \%)$ \\
Hypertension & $5(8 \%)$ & $5(8 \%)$ & $10(8 \%)$ \\
Low Back Pain & $1(2 \%)$ & $0(0 \%)$ & $1(1 \%)$ \\
Bronchiectasis & $3(5 \%)$ & $3(5 \%)$ & $6(5 \%)$ \\
Pulmonary mass & $9(14 \%)$ & $2(3 \%)$ & $11(9 \%)$ \\
CPC* & $1(2 \%)$ & $1(2 \%)$ & $2(2 \%)$ \\
Anemia & $1(2 \%)$ & $2(3 \%)$ & $3(3 \%)$ \\
Candidiasis Oral & $1(2 \%)$ & $0(0 \%)$ & $1(1 \%)$ \\
OA Acute* & $1(2 \%)$ & $0(0 \%)$ & $1(1 \%)$ \\
Tuberculosis & $6(9 \%)$ & $5(8 \%)$ & $11(9 \%)$ \\
CHF* & $3(5 \%)$ & $2(3 \%)$ & $5(4 \%)$
\end{tabular}




\begin{tabular}{|c|c|c|c|}
\hline Diabetes Mellitus & $3(5 \%)$ & $6(9 \%)$ & $9(7 \%)$ \\
\hline Pleural Effusion & $2(3 \%)$ & $1(2 \%)$ & $3(3 \%)$ \\
\hline Hypokalemia & $1(2 \%)$ & $0(0 \%)$ & $1(1 \%)$ \\
\hline HHD* & $0(0 \%)$ & $1(2 \%)$ & $1(1 \%)$ \\
\hline Dyspepsia & $0(0 \%)$ & $2(3 \%)$ & $2(2 \%)$ \\
\hline Cholestasis & $0(0 \%)$ & $1(2 \%)$ & $1(1 \%)$ \\
\hline Limfadeatitis & $0(0 \%)$ & $1(2 \%)$ & $1(1 \%)$ \\
\hline Lung Abscess & $1(2 \%)$ & $0(0 \%)$ & $1(1 \%)$ \\
\hline Hemophilic & $1(2 \%)$ & $0(0 \%)$ & $1(1 \%)$ \\
\hline Lung Adenoma & $1(2 \%)$ & $0(0 \%)$ & $1(1 \%)$ \\
\hline Bronchitis & $1(2 \%)$ & $0(0 \%)$ & $1(1 \%)$ \\
\hline Persistent Asma & $0(0 \%)$ & $1(2 \%))$ & $1(1 \%)$ \\
\hline NSTEMI & $0(0 \%)$ & $1(2 \%)$ & $1(1 \%)$ \\
\hline Thrombocytopenia & $0(0 \%)$ & $1(2 \%)$ & $1(1 \%)$ \\
\hline Hepatitis & $0(0 \%)$ & $2(3 \%)$ & $2(2 \%)$ \\
\hline Kidney Failure & $0(0 \%)$ & $1(2 \%)$ & $1(1 \%)$ \\
\hline Malnutrition & $0(0 \%)$ & $1(2 \%)$ & $1(1 \%)$ \\
\hline Kidney Cyst & $0(0 \%)$ & $1(2 \%)$ & $1(1 \%)$ \\
\hline \multicolumn{4}{|c|}{ * COPD: Chronic Obstructive Pulmonary Disease } \\
\hline \multicolumn{4}{|c|}{ * COPD Ex: Chronic Obstructive Pulmonary Disease Exacerbation } \\
\hline \multicolumn{4}{|c|}{ *CPC: Cor Pulmonale Chronicum } \\
\hline \multicolumn{4}{|c|}{ *OA Acute: Osteoarthritis Acute } \\
\hline \multicolumn{4}{|c|}{ *CHF: Congestive Heart Failure } \\
\hline
\end{tabular}

Based on Table 2, from the total number of the two groups, the most common types of comorbid were pulmonary mass by $9 \%$, tuberculosis by $9 \%$, COPD by $8 \%$, hypertension by $8 \%$, diabetes mellitus by $7 \%$, COPD exacerbations by $6 \%$, and Bronchiectasis (BE) by $5 \%$.

In table 3 , the most common single antibiotic used was levofloxacin, with total use of 34\%. These included 14 $(39 \%)$ data on smoking patients and $10(28 \%)$ data on nonsmoking patients.

In table 4, the most common use of combined antibiotic therapy in pneumonia patients was the combination of levofloxacin + ceftazidime in both group. For the levofloxacin + ceftazidime combination in the smoking group, there were 12 or $41 \%$ of patients, while in the nonsmoking group, 11 or $38 \%$ of patients used it.

In table 5, the antibiotic class that is most used in pneumonia patients in the two study groups was the fluoroquinolone class and sefalosporin class.

In table 6 , the most administered electrolyte fluid in pneumonia patients in both groups was Ringer lactate infusion by $72 \%$ for 93 patients. For cough reliever, the most common drug given to pneumonia patients in both groups was $82 \%$ acetylcysteine $200 \mathrm{mg}$ capsules for 106 patients.

Table 3. Overview of the use of a single antibiotic

\begin{tabular}{lccc} 
Antibiotics & $\begin{array}{c}\text { Smoking } \\
\text { Group } \\
(\mathbf{n = 3 6 )}\end{array}$ & $\begin{array}{c}\text { Non- } \\
\text { Smoking } \\
\text { Group } \\
(\mathbf{n = 3 6 )}\end{array}$ & Total \\
\hline Levofloxacin & $14(39 \%)$ & $10(28 \%)$ & $\begin{array}{c}24 \\
(34 \%)\end{array}$ \\
Meropenem & $5(14 \%)$ & $2(6 \%)$ & $7(10 \%)$ \\
Ceftazidine & $9(25 \%)$ & $13(36 \%)$ & 22 \\
Ceftriaxone & $6(17 \%)$ & $6(17 \%)$ & $\begin{array}{c}131 \%) \\
\text { Cefoperazone }\end{array}$ \\
Moxifloxacin & $2(5 \%)$ & $3(8 \%)$ & $5(7 \%)$ \\
Azithromycin & $0(0 \%)$ & $1(3 \%)$ & $1(1 \%)$ \\
& & $1(1 \%)$ \\
\hline
\end{tabular}

Tabel 4. Overview of the use of combined antibiotics

\begin{tabular}{lccc}
\multicolumn{1}{c}{ Antibiotics } & $\begin{array}{c}\text { Smoking Group } \\
(\mathbf{n = 2 9 )}\end{array}$ & $\begin{array}{c}\text { Non-Smoking Group } \\
(\mathbf{n = 2 9 )}\end{array}$ & Total \\
\hline Levofloxacin + Ceftazidine & $12(41 \%)$ & $11(38 \%)$ & $23(40 \%)$ \\
\hline $\begin{array}{l}\text { Ceftazidine + Metronidazole + } \\
\text { Levofloxacin + Meropenem }\end{array}$ & $1(3 \%)$ & $0(0 \%)$ & $1(2 \%)$ \\
\hline Azithromycin + Levofloxacin & $1(3 \%)$ & $2(7 \%)$ & $3(5 \%)$ \\
\hline Levofloxacin + Metronidazole & $1(3 \%)$ & $1(3 \%)$ & $2(3 \%)$ \\
\hline $\begin{array}{l}\text { Ceftazidine + Azithromycin + } \\
\text { Metronidazole }\end{array}$ & $1(3 \%)$ & $0(0 \%)$ & $1(2 \%)$ \\
\hline
\end{tabular}




\begin{tabular}{lccc}
\hline Levofloxacin + Meropenem & $4(14 \%)$ & $3(10 \%)$ & $7(12 \%)$ \\
\hline Meropenem + Azithromycin & $1(3 \%)$ & $0(0 \%)$ & $1(2 \%)$ \\
\hline Levofloxacin + Cefoperazone & $1(3 \%)$ & $0(0 \%)$ & $1(2 \%)$ \\
\hline Ceftazidine + Azithromycin & $2(7 \%)$ & $2(7 \%)$ & $4(7 \%)$ \\
\hline $\begin{array}{l}\text { Ceftriaxone + Azithromycin + } \\
\text { Levofloxacin + Cefoperazone }\end{array}$ & $1(3 \%)$ & $0(0 \%)$ & $1(2 \%)$ \\
\hline Levofloxacin + Ceftriaxone & $1(3 \%)$ & $3(10 \%)$ & $4(7 \%)$ \\
\hline Ceftazidine + Gentamycin & $1(3 \%)$ & $1(3 \%)$ & $2(3 \%)$ \\
\hline Moxifloxacin + Meropenem & $1(3 \%)$ & $0(0 \%)$ & $5(9 \%)$ \\
\hline Azithromycin + Ceftriaxone & $1(3 \%)$ & $4(14 \%)$ & $1(2 \%)$ \\
\hline $\begin{array}{l}\text { Ceftazidine + Azithromycin }+ \\
\text { Levofloxacin }\end{array}$ & $0(0 \%)$ & $1(3 \%)$ & $1(2 \%)$ \\
\hline $\begin{array}{l}\text { Ceftazidine + Meropenem }+ \\
\text { Levofloxacin }\end{array}$ & $0(0 \%)$ & $1(3 \%)$ & 5 \\
\hline
\end{tabular}

Table 5. Description of the use of antibiotics class

\begin{tabular}{|c|c|c|c|c|}
\hline Class & Antibiotics & $\begin{array}{l}\text { Smoking Group } \\
\qquad(n=65)\end{array}$ & $\begin{array}{l}\text { Non-Smoking Group } \\
\qquad(\mathrm{n}=65)\end{array}$ & Total \\
\hline \multirow[t]{3}{*}{ Sefalosforin } & Ceftazidine & $26(29 \%)$ & $29(35 \%)$ & $55(32 \%)$ \\
\hline & Ceftriaxone & $9(10 \%)$ & $13(16 \%)$ & $22(13 \%)$ \\
\hline & Cefoperazone & $4(5 \%)$ & $3(3 \%)$ & $7(4 \%)$ \\
\hline Carbapenem & Meropenem & $12(14 \%)$ & $6(7 \%)$ & $18(10 \%)$ \\
\hline \multirow[t]{2}{*}{ Fluoroquinolone } & Levofloxacin & $36(55 \%)$ & $32(49 \%)$ & $68(52 \%)$ \\
\hline & Moxifloxacin & $1(1 \%)$ & $1(1 \%)$ & $2(1 \%)$ \\
\hline Makrolida & Azithromycin & $7(8 \%)$ & $10(12 \%)$ & $17(10 \%)$ \\
\hline Nitroimidazole & Metronidazole & $3(3 \%)$ & $1(1 \%)$ & $4(2 \%)$ \\
\hline Aminoglikosida & Gentamycin & $1(1 \%)$ & $1(1 \%)$ & $2(1 \%)$ \\
\hline
\end{tabular}

Besides, the asthma reliever most widely used in both groups included. Combivent nebules pro by $60 \%$ for 78 patients and Pulmicort $0.25 \mathrm{mg}$ respules by $60 \%$ for 78 patients. For corticosteroid drugs, most given to patients was an injection of methylprednisolone $125 \mathrm{mg} / \mathrm{ml}$ by $57 \%$ for 74 patients. Meanwhile, the febrifuge drug mostly given to patients with pneumonia was paracetamol $500 \mathrm{mg}$ tablets by $28 \%$ for 36 patients. Table 7 shows 53 or $82 \%$ of patients with pneumonia in the smoking group with a length of stay $\leqslant 5$ days. Besides, in Table 8 , in the smoking group of pneumonia, patients with 'cured' status were 17 or $26 \%$ of patients, patients with 'improved' status were 40 or $61 \%$ of patients, and patients with 'not-yet-cured' status were eight or $13 \%$ of patients. As for the non-smoking group, the effectiveness of therapy in 'cured' status was $47 \%$ with 31 patients, 'improved' status was $43 \%$ with 28 patients, and 'not cured' status was $10 \%$ with six patients.

Table 6. Overview of non-antibiotic use

\begin{tabular}{c|l|c|c|c}
\hline \multirow{2}{*}{ Category } & \multicolumn{1}{c|}{ Drugs Name } & $\begin{array}{c}\text { Smoking Group } \\
(\mathbf{n}=65)\end{array}$ & $\begin{array}{c}\text { Non-Smoking Group } \\
(\mathbf{n}=65)\end{array}$ & Total \\
\hline \multirow{2}{*}{ Asthma } & Pulmicort repsule $0,25 \mathrm{mg}$ & $36(56 \%)$ & $42(65 \%)$ & $78(60 \%)$ \\
Reliever & Combivent nebules pro & $44(68 \%)$ & $34(52 \%)$ & $78(60 \%)$ \\
& Flixotide nebule & $13(20 \%)$ & $7(11 \%)$ & $20(15 \%)$ \\
& Meptin 0,5 inhalation sol & $8(12 \%)$ & $7(11 \%)$ & $15(12 \%)$
\end{tabular}




\begin{tabular}{|c|c|c|c|c|}
\hline & Meptin swinghaler & $1(2 \%)$ & $3(4 \%)$ & $4(3 \%)$ \\
\hline & Salbulin inhaler & $2(3 \%)$ & $4(6 \%)$ & $6(5 \%)$ \\
\hline & Bricasma nebule & $7(11 \%)$ & $4(6 \%)$ & $11(8 \%)$ \\
\hline & Bricasma injeksi $0,5 \mathrm{mg} / \mathrm{ml}$ & $3(4 \%)$ & $0(0 \%)$ & $3(3 \%)$ \\
\hline & Berotec inhaler & $7(11 \%)$ & $9(13 \%)$ & $16(12 \%)$ \\
\hline & Ventolin inhaler $100 \mathrm{mcg}$ & $2(3 \%)$ & $1(2 \%)$ & $3(3 \%)$ \\
\hline & Ventolin nebule $2,5 \mathrm{mg}$ & $7(11 \%)$ & $8(12 \%)$ & $15(12 \%)$ \\
\hline & Symbicort turbuhaler $80 / 4,5$ & $0(0 \%)$ & $1(2 \%)$ & $1(1 \%)$ \\
\hline & Symbicort turbuhaler $160 \mathrm{mcg}$ & $14(21 \%)$ & $10(15 \%)$ & $24(18 \%)$ \\
\hline & Spririva combopack & $11(17 \%)$ & $5(8 \%)$ & $16(12 \%)$ \\
\hline & Spiriva refill & $2(3 \%)$ & $4(6 \%)$ & $6(5 \%)$ \\
\hline & Aminofilin injeksi $24 \mathrm{mg} / \mathrm{ml}$ & $14(21 \%)$ & $11(17 \%)$ & $25(19 \%)$ \\
\hline & Salbutamol $2 \mathrm{mg}$ tablet & $11(17 \%)$ & $2(3 \%)$ & $13(10 \%)$ \\
\hline & Seretide discus $250 \mathrm{mcg}$ & $4(6 \%)$ & $4(6 \%)$ & $8(6 \%)$ \\
\hline & Seretide discus $500 \mathrm{mcg}$ & $3(4 \%)$ & $2(3 \%)$ & $5(4 \%)$ \\
\hline & Molasma 2,5 mg & $4(6 \%)$ & $9(13 \%)$ & $13(10 \%)$ \\
\hline & Terbutaline $2,5 \mathrm{mg}$ & $1(2 \%)$ & $0(0 \%)$ & $1(1 \%)$ \\
\hline & Rethapyl SR $300 \mathrm{mg}$ & $12(18 \%)$ & $10(15 \%)$ & $22(17 \%)$ \\
\hline & Bronsolvan $150 \mathrm{mg}$ & $3(4 \%)$ & $1(2 \%)$ & $4(3 \%)$ \\
\hline & Acetylcystein $200 \mathrm{mg}$ tab & $55(85 \%)$ & $51(79 \%)$ & $106(82 \%)$ \\
\hline & Fluimucyl $100 \mathrm{mg} / \mathrm{ml}$ sirup & $6(9 \%)$ & $1(2 \%)$ & $7(6 \%)$ \\
\hline & Ambroxol sirup $15 \mathrm{mg} / \mathrm{ml}$ & $32(49 \%)$ & $37(57 \%)$ & $69(53 \%)$ \\
\hline & Ambroxol $30 \mathrm{mg}$ tablet & $9(13 \%)$ & $16(25 \%)$ & $25(19 \%)$ \\
\hline Cough & Codein $10 \mathrm{mg}$ & $2(3 \%)$ & $2(3 \%)$ & $4(3 \%)$ \\
\hline Reliever & Codein $20 \mathrm{mg}$ & $3(4 \%)$ & $4(6 \%)$ & $7(5 \%)$ \\
\hline & Gliseril Guaikolat 100 mg & $0(0 \%)$ & $1(2 \%)$ & $1(1 \%)$ \\
\hline & Bromheksin $8 \mathrm{mg}$ tablet & $0(0 \%)$ & $1(2 \%)$ & $1(1 \%)$ \\
\hline & OBH sirup $100 \mathrm{ml}$ & $1(2 \%)$ & $1(2 \%)$ & $2(2 \%)$ \\
\hline & Rhinathiol $375 \mathrm{mg}$ & $1(2 \%)$ & $1(2 \%)$ & $2(2 \%)$ \\
\hline & Parasetamol $500 \mathrm{mg}$ tablet & $23(36 \%)$ & $13(20 \%)$ & $36(28 \%)$ \\
\hline Antipyretic & Parasetamol infus & $2(3 \%)$ & $1(2 \%)$ & $3(3 \%)$ \\
\hline & Tera $\mathrm{F}$ & $5(8 \%)$ & $6(9 \%)$ & $11(8 \%)$ \\
\hline & Metilprednisolon $4 \mathrm{mg}$ & $10(15 \%)$ & $2(3 \%)$ & $12(9 \%)$ \\
\hline Corticosteroid & Metilprednisolon $8 \mathrm{mg}$ & $4(6 \%)$ & $3(4 \%)$ & $7(6 \%)$ \\
\hline & Metilprednisolon $125 \mathrm{mg}$ injeksi & $38(59 \%)$ & $36(56 \%)$ & $74(57 \%)$ \\
\hline
\end{tabular}




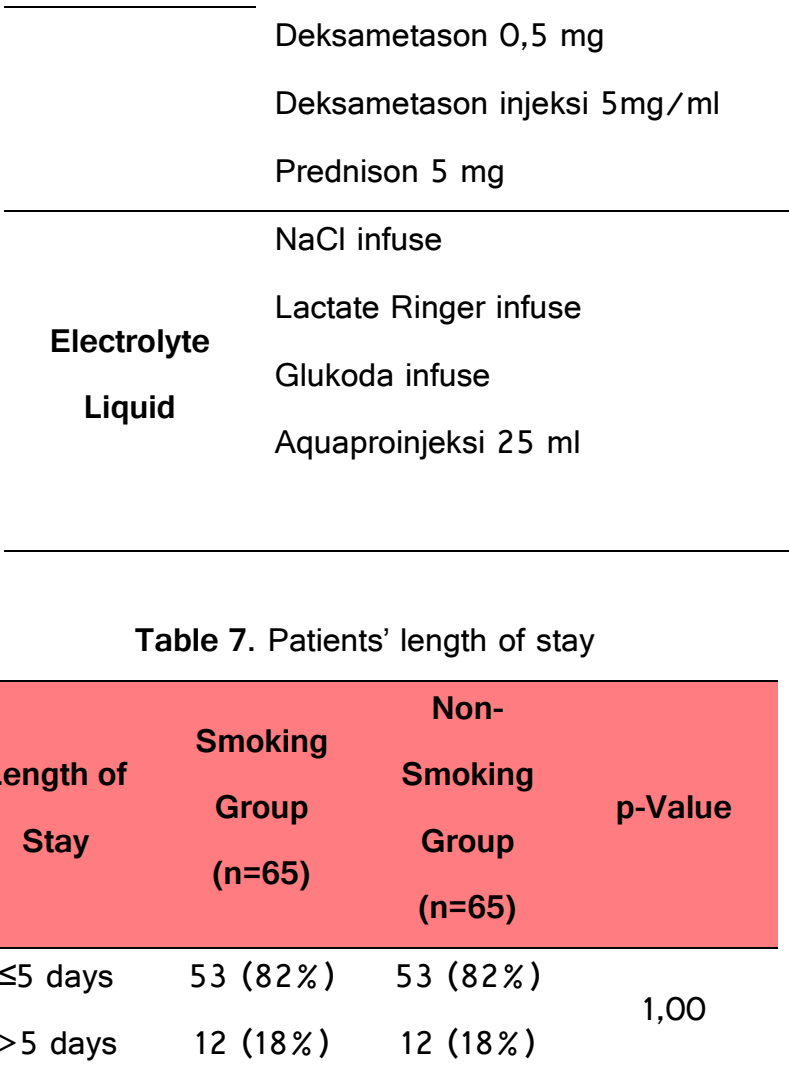

$0(0 \%)$

$17(26 \%)$

$1(2 \%)$

$1(1 \%)$

$0(0 \%)$

$11(17 \%)$

$28(22 \%)$

$30(46 \%)$

$1(2 \%)$

$1(1 \%)$

$48(74 \%)$

$0(0 \%)$

$48(74 \%)$

$26(40 \%)$
$45(69 \%)$
$4(6 \%)$

$50(77 \%)$
$56(43 \%)$

$93(72 \%)$

$4(3 \%)$

$98(76 \%)$

\section{DISCUSSION}

To obtain data on patient characteristics based on age, a statistical analysis was performed using the Chi-square test to determine the proportion of age in both groups. The analysis results uncovered that the $\mathrm{p}$-value $>0.05$ was 0.226 . The p-value of 0.226 statistically indicated that the proportion of age from late adolescence to the elderly in both groups was evenly distributed. The smoking group and the non-smoking group were homogeneous.

According to Kemenkes RI, the Ministry of Health of Indonesia the population susceptible to pneumonia is a group of children aged $<2$ years, elderly patients $>65$ years, and patients with health problems, such as malnutrition and immunological disorders. In elderly patients, interference with malnutrition is a major cause of immunological disorders[10]. Malnutrition in elderly patients is due to a deficiency of calories, protein, and nutrients such as vitamins and minerals. Therefore, if the patient is malnourished, the immune system will decrease[11]. Apart from malnutrition, the incidence of pneumonia in the elderly continues to increase due to changes in pulmonary physiology anatomy. Changes in pulmonary physiological anatomy can result in changes in the lung organ reserves' function, the ability to cope with decreased lung function, and a decreased immunity.
Table 8. Therapy effectiveness of pneumonia patients

\begin{tabular}{cccc}
$\begin{array}{c}\text { Therapy } \\
\text { Effectiveness }\end{array}$ & $\begin{array}{c}\text { Smoking } \\
\text { Group } \\
(\mathrm{n}=65)\end{array}$ & $\begin{array}{c}\text { Non- } \\
\text { Smoking } \\
\text { Group } \\
(\mathrm{n}=65)\end{array}$ & p-Value \\
\hline Cured & $17(26 \%)$ & $31(47 \%)$ & 0,039 \\
Improved & $40(61 \%)$ & $28(43 \%)$ & \\
Not-yet-cured & $8(13 \%)$ & $6(10 \%)$ & \\
\hline
\end{tabular}

\subsection{Accompanying diseases}

The data analysis results using the Chi-square statistical test obtained p-value> 0.05 of 0.652 . A p-value of 0.652 signified that there was no significant difference in the comorbidity status of the smoking and the non-smoking groups. Thus, there was no difference between groups in contracting accompanying diseases.

Based on Table 2, the most common types of comorbidities were pulmonary mass $(95 \%)$, tuberculosis (9\%), COPD (8\%), hypertension (8\%), Diabetes Mellitus (7\%), COPD exacerbations (6\%), and Bronchiectasis (5\%). Pulmonary mass or lung cancer is a disease caused by abnormal growth in the lungs. The leading cause is microorganisms, such as Streptococcus pneumonia, Streptococcus aureus, Haemophilus influenza, Klebsiella pneumonia, Enterobacter cloacae, and Pseudomonas aeruginosa. Apart from microorganisms, lung cancer can occur due to bronchial damage, immunosuppression, localhost disruption due to tumor invasion, necrosis of normal tissue, and tumors[12].

Patients who have a smoking habit can inhibit cilia movement in the respiratory tract and cause inflammation of the parenchyma in the lungs. The cigarette contents will enter the lung tissue, resulting in a carcinogenesis process followed by inflammation of the lung cells and stroma[13]. The carcinogen contents in the cigarette can activate metabolism and cause reactions with DNA. Therefore, there 
will be persistent changes. The existence of persistent changes in DNA causes miscoding during replication resulting in permanent mutations in RAS, MYC oncogene, and Tp53, which are the cause of cancer. Nicotine and carcinogens will bind directly to the inactivation process of protein kinase $\mathrm{A}$ and protein kinase $\mathrm{B}$, which results in decreased apoptosis, increased angiogenesis and increased cell transformation[14].

\subsection{Use of antibiotics}

Patients diagnosed with pneumonia will receive therapies, one of which is antibiotics. In this study, antibiotics were given as empiric antibiotics to determine the cause of pneumonia because there was no culture examination data before. For the results of patient characteristics regarding the use of antibiotics, statistical tests were performed employing the Chi-square test. The results obtained from the statistical test was 1,000 , which was the $p$-value $>0.05$. If the $p$-value of $>0.05$ was 1,000 , it denoted no significant difference in the proportion of single and combined antibiotic use in the smoking and nonsmoking groups. It signified that both the smoking and the non-smoking groups received antibiotic therapy in single and combined forms.

\subsection{Use of non-antibiotics}

Hospitalized pneumonia patients are not only given antibiotic treatment but are also given non-antibiotic drugs to reduce pneumonia symptoms. Common pneumonia symptoms include coughing, excessive sputum production, fever, shortness of breath, and crackles[11]. Shortness of breath can occur in patients with pneumonia due to decreased sensitivity of the respiratory center to hypoxia or hypercapnia, which results in a loss of ventilatory response in the lungs.

In pneumonia patients, administration of electrolyte fluids such as $0.9 \% \mathrm{NaCl}$ and ringer lactate serves to restore body fluids or restore tissue perfusion and hydration because when patients were hospitalized, fluid body imbalance may occur. Giving electrolyte fluids can restore lost body fluids. Besides experiencing electrolyte fluid imbalance, patients also experience coughing. There are three kinds of cough medicine: expectorant, mucolytic, and antitussive. However, in the cases of pneumonia infection, patients are given expectorant and mucolytic as cough medicines. These cough medicines aim to help thin phlegm and help expel phlegm. Giving these drugs can relieve the symptoms.

In patients with pneumonia, other symptoms that will appear are shortness of breath. Patients who experience shortness of breath symptoms will be given asthma medications or relievers, aiming to ease the breathing difficulty. Besides, other symptoms that appear in pneumonia patients are fever. Fever can occur due to infection in the lungs caused by foreign substances such as bacteria. In this case, patients with pneumonia who experience fever will be given a fever-reducing drug, namely paracetamol. The use of paracetamol aims to reduce fever in pneumonia patients. In patients with pneumonia, non-antibiotic drugs given are corticosteroids. The use of corticosteroid drugs in pneumonia patients aims to reduce inflammation in the lungs[15].

\subsection{Therapy Outcome}

The parameters used to measure therapy outcomes in this study were the length of stay and therapy effectiveness. In this study, patients' length of stay was grouped into two categories: $\leq 5$ days and $>5$ days. Based on Dipiro's (2015) observation, pneumonia patients will experience recovery on the $5^{\text {th }}$ day of antibiotic administration[16]. Meanwhile, according to the American Thoracic Society (ATS), the minimum use of antibiotics is five days. Thus, the researchers divided the length of stay into two categories to determine the difference in length of stay in smoking and non-smoking patients[17].

The analysis using chi-square showed the value of 1,00. A value of $p>0,05$ indicated that there was no significant difference between the two groups. Thus, the length of stay in patients with pneumonia between patients with and without a smoking history did not differ. It is not in accordance with the hypothesis, stating that there is a significant difference between pneumonia patients with and without a smoking history. There are five factors that proven to do not have any significant correlation with length of stay; age, gender, alcohol intake, smoking and existing illness[18]. While polutant standart index (PSI), pleural effusion, the concentration of BUN and number of lobes affected were observed to be significantly correlated positive[18]. The main reason of hospital admission among community acquired pneumonia (CAP) patients is respiratory insufficiency, which is a morbidity and mortality risk factors among those patients[18].

According to Monita and Osharinanda (2015), patient hospitalization can be influenced by several factors, such as nutritional status, disease severity, and types of accompanying diseases or comorbidities[19]. The accompanying diseases will affect the patient's length of stay, which will extend it. The more comorbid a patient is, the more it will affect the healing process, which will slow it down.

Another factor affecting the length of stay is age. It is influenced by physiological pulmonary anatomy caused by changes in reserve lung function and decreased immunity. In table 2 on the types of comorbidities, comorbidities that occurred in smoking groups were COPD Exacerbations, Hypertension, Pulmonary Mass, Bronchiectasis, Tuberculosis, Diabetes Mellitus, and COPD.

In this study, there was no difference in the proportion of the length of stay between smoking and non-smoking patients. According to other studies, the ratio of patients who smoke to patients who do not smoke represents a reduced hospitalization rate or length of stay in pneumonia patients. As for the patients who quit smoking, the risk of the length of stay also decreased. In all study participants, in this case, smoking and non-smoking patients, the results 
confirmed no difference in the risk of the length of stay in pneumonia patients[11].

The outcome of the therapy effectiveness can be seen from the status card when patients discharge or leave the hospital. This study's discharge categories were made into three: 'cured', 'improved', and 'not-yet-cured'. Pneumonia patients who returned in a cured condition were patients who had no pneumonia symptoms and were allowed to go home by a doctor. Patients with 'improved' status had pneumonia symptoms decreased and were allowed to go home by the doctor. Patients with 'not-yet-cured' status were patients who still experienced pneumonia symptoms or have not improved and were still in a state of illness, but the patients wanted to go home and were allowed to go home by the doctor.

Based on the statistical analysis results using the chisquare test, the value of 0.039 was obtained. $\mathrm{P}$ of $<0.05$ indicated that there was a significant difference in the smoking group and the non-smoking group. The difference in therapy effectiveness was caused by several factors, including age, smoking status, lung function, comorbidities, and length of stay. Elderly patients (> 65 years) are susceptible to pneumonia because of lung function changes and decreased immunity. As people get older, the body's physiological functions, immune system, and lung function will decrease.

Furthermore, people with the current smoking status were at higher risk to be infected by bacteria pneumonia compared to those former one[20]. A wide spectrum of communicable diseases including viral and bacterial pathogens has been associated with current smoking status[21]. The therapy effectiveness, which is related to protective functions of airway epithelium, alveolar macrophages, dendritic cells, natural killer cells and adaptive immune mechanism is correlated with smoking cigarettes suppressive effect[22]. Moreover, the ICU admission required by patients and the need for mechanical ventilation as well vasopressors was higher among those current smoking group compared to non-smokers one[23].

\section{CONCLUSION}

The effectiveness of therapy in the smoking group had a $26 \%$ chance of recovery, an improvement of $61 \%$, and notyet-cured of $13 \%$. Meanwhile, in the non-smoking group, they had a $47 \%$ chance of recovery, an improvement of $43 \%$ and not-yet-cured of $10 \%$. The statistical test results with Chi-square obtained $\mathrm{p}$-value of $<0.05(\mathrm{p}=0.039)$. The results on the length of stay showed that $82 \%$ of patients in the smoking group and non-smoking group had a length of stay of $\leq 5$ days, and $12 \%$ of patients had a length of stay of $>5$ days in both group. Hence, smoking habits significantly affected therapy's effectiveness but did not significantly influence the length of stay.

\section{RESEARCH LIMITATION}

Future researchers who will conduct similar studies can use the prospective method. Meanwhile, health workers can make more complete observations regarding patients' data, disease history, and smoking duration to determine the disease's cause.

\section{ACKNOWLEDGMENTS}

This research was supported by a grant from Muhammadiyah Tobacco Control Center (MTCC) Universitas Muhammadiyah Yogyakarta.

\section{REFERENCES}

[1] Nurjazuli, Widyaningtyas R. Faktor Risiko Dominan Kejadian Pnumonia Pada Balita ( Dominant risk factors on the occurrence of pneumonia on children under five years). $J$ Respirologi 2006; 1-21.

[2] Pusat Data dan Informasi Kementerian Kesehatan RI. Situasi Umum Konsumsi Tembakau di Indonesia (Current Tobacco Consumption in Indonesia),

http://www.depkes.go.id/resources/download/pusd atin/infodatin/infodatin tembakau per halaman.pdf (2018).

[3] Huttunen R, Heikkinen T, Syrjänen J. Smoking and the outcome of infection. J Intern Med 2011; 269: 258-269.

[4] Shinohara T, Kadota N, Hino H, et al. Improvement in idiopathic nonspecific interstitial pneumonia after smoking cessation. Respir Med Case Reports 2015; 14: 7-9.

[5] Mahishale V, Patil B, Lolly M, et al. Prevalence of Smoking and Its Impact on Treatment Outcomes in Newly Diagnosed Pulmonary Tuberculosis Patients: A Hospital-Based Prospective Study. Chonnam Med J 2015; 51: 86.

[6] Yen YF, Yen MY, Lin YS, et al. Smoking increases risk of recurrence after successful anti-tuberculosis treatment: A population-based study. Int J Tuberc Lung Dis 2014; 18: 492-498.

[7] Balian DR, Davtyan K, Balian A, et al. Tuberculosis treatment and Smoking, Armenia, 2014-2016. J Clin Tuberc Other Mycobact Dis 2017; 8: 1-5.

[8] Cecere LM, Williams EC, Sun H, et al. Smoking cessation and the risk of hospitalization for pneumonia. Respir Med 2012; 106: 1055-1062.

[9] $\mathrm{Xu}$ X, Bishop EE, Kennedy SM, et al. Annual healthcare spending attributable to cigarette smoking: An update. Am J Prev Med 2015; 48: 326-333.

[10] Kesehatan K, Indonesia R. profil-kesehatanIndonesia-2015. 
[11] Sari, Elza Febria; Rumende, C Martin; Harimurti K. Factors Related to Diagnosis of CommunityAcquired Pneumonia in the Elderly. J Penyakit Dalam Indones 2016; 3: 183-192.

[12] Avcı N, Hartavi M, Kaçan T, et al. Retrospective analysis of the microbiological spectrum of pneumonia in Turkish patients with lung cancer. Epub ahead of print 2011. DOI: 10.5114/wo.2016.58502.

[13] Simonsen DF, Søgaard M, Bozi I, et al. Risk factors for postoperative pneumonia after lung cancer surgery and impact of pneumonia on survival. Respir Med 2015; 109: 1340-1346.

[14] Denholm R, Schüz J, Straif K, et al. Is previous respiratory disease a risk factor for lung cancer? Am J Respir Crit Care Med 2014; 190: 549-559.

[15] Sibila O, Agustí C, Torres A. Corticosteroids in severe pneumonia. Eur Respir J 2008; 32: 259-264.

[16] S. T. Wells BG, Dipiro JT DC. No Title. ninth. McGraw-Hill Education Companies, 2015.

[17] Mandell LA, Wunderink RG, Anzueto A, et al. Infectious Diseases Society of America/American Thoracic Society Consensus Guidelines on the management of community-acquired pneumonia in adults. Clin Infect Dis; 44. Epub ahead of print 2007. DOI: 10.1086/511159.
[18] Menéndez R, Cremades MJ, Martínez-Moragón E, et al. Duration of length of stay in pneumonia: Influence of clinical factors and hospital type. Eur Respir J 2003; 22: 643-648.

[19] Monita O, Yani FF, Lestari Y. Artikel Penelitian Profil Pasien Pneumonia Komunitas di Bagian Anak RSUP. J Kesehat Andalas 2012; 4: 218-226.

[20] De P, Farley A, Lindson N, et al. Systematic review and meta-analysis: Influence of smoking cessation on incidence of pneumonia in HIV. BMC Med; 11. Epub ahead of print 2013. DOI: 10.1186/17417015-11-15.

[21] Baskaran V, Murray RL, Hunter A, et al. Effect of tobacco smoking on the risk of developing community acquired pneumonia: A systematic review and meta-analysis. PLoS One 2019; 14: 118.

[22] Feldman C, Anderson R. Cigarette smoking and mechanisms of susceptibility to infections of the respiratory tract and other organ systems. $J$ Infect 2013; 67: 169-184.

[23] Alroumi F, Abdul Azim A, Kergo R, et al. The impact of smoking on patient outcomes in severe sepsis and septic shock. J Intensive Care 2018; 6: $1-11$. 